\title{
Pengembangan Media Komik Interaktif Cerita Mbojo Berbasis Gerakan Literasi Sekolah untuk Meningkatkan Minat Baca Siswa
}

\author{
Nunung Fatimah ${ }^{1}$, Surya Ningsyih ${ }^{2}$ \\ ${ }^{12}$ Program Studi PGSD; STKIP Taman Siswa Bima \\ Email : nunungfatimah95@gmail.com
}

\begin{abstract}
Reading is part of literacy in the lower grades carried out at school. At the elementary school level, literacy activities are the starting point for understanding other sciences. The success of the early stages is crucial for advancing to the next level. Effective literacy teaching in the early grades needs to pay attention to the learning environment and materials that suit the needs of students so that researchers are interested in conducting development research in this study specifically for low-grade students and for the place of research that is carried out at SDN Sari Kalampa. The development of interactive comic media for the Mbojo story based on the school literacy movement to increase students' reading interest carried out at SDN Sari Kalampa, Woha District, Bima Regency is very necessary. The purpose of this study is to find out the importance of using or developing a comic medium for the Mbojo story where this media will be reading material that aims to increase literacy activities. The results showed that the learning media for interactive comics based on the mbojo story based on the school literacy movement could increase students' reading interest with the average score of student responses being 4,47 which was included in the "very good" category and the teacher's response was 4,72 which meant the "very good" category.
\end{abstract}

Keywords: Development, Comic Media, Literacy Movement

\begin{abstract}
Abstrak
Membaca merupakan bagian dari literasi di kelas rendah yang dilakukan di sekolah. Pada tingkat sekolah dasar kegiatan literasi merupakan titik awal untuk memahami ilmu yang lain. Keberhasilan tahap awal sangat menentukan untuk melesat maju pada tingkat berikutnya. Pengajaran literasi yang efektif di kelas awal perlu memperhatikan lingkungan belajar dan materi yang sesuai dengan kebutuhan siswa sehingga peneliti tertarik malakukan penelitian pengembangan dalam penelitian ini khusus untuk siswa kelas rendah dan untuk tempat penelitian yaitu dilakukan di SDN Sari Kalampa. Pengembangan media komik interaktif cerita Mbojo berbasis gerakan literasi sekolah untuk meningkatkan minat baca siswa yang dilakukan di SDN Sari Kalampa Kecamatan Woha Kabupaten Bima sangat di perlukan. Tujuan penelitian ini untuk mengetahui pentingnya pengunaan atau pengembangan sebuah media komik cerita Mbojo yang dimana media ini akan menjadi bahan bacaan yang bertujuan untuk meningkatan kegiatan literasi. Hasil penelitian menunjukan bahwa media pembelajaran komik interaktif cerita mbojo berbasis gerakan literasi sekolah dapat meningkatkan minat membaca siswa dengan skor rata-rata dari respon siswa yaitu 4,47 yang termasuk katogori "sangat baik" dan respon guru yaitu 4,72 yang termaksud kategori "sangat baik".
\end{abstract}

Kata Kunci: Pengembangan, Media Komik, Gerakan Literasi

\section{PENDAHULUAN}

Media pembelajaran merupakan alat atau perantara yang berguna untuk memudahkan proses belajar mengajar dalam mengefektifkan komunikasi antara pengajar dan pendidik, hal ini berarti memudahkan guru dalam mengajar serta memudahkan siswa menerima pembelajaran. Proses ini membutuhkan guru yang mampu menyelaraskan antara media pembelajaran dalam proses belajar mengajar, juga dapat membangkitkan keinginan dan minat baru bagi seluruh siswa dan membangkitkan motivasi belajar serta membawa pengaruh positif terhadap psikologis perkembangan siswa. Media pembelajaran memiliki peran yang dapat menunjang keberhasilan kegiatan pembelajaran yaitu dengan menggunaan media pembelajaran yang tepat maka akan memberikan dampak yang lebih baik pada hasil pembelajaran. Media dapat digunakan untuk mengembangkan kemampuan siswa dalam menggali informasi dan memahami materi pembelajaran yang diajarkan. Hal ini sesuai dengan yang diungkapkan Ahmad Susanto (2013:46) yang mengatakan bahwa media pembelajaran dapat menumbuhkan motivasi siswa agar dapat mengingat pelajaran dengan mudah, menyediakan stimulus belajar, siswa menjadi aktif dalam merespon, memberi umpan balik dengan cepat, dan menghindari kebosanan siswa dalam proses pembelajaran. 
Bertolak dari uraian tersebut, usaha mengembangkan media komik yang layak untuk meningkatkan efektivitas dan produktivitas membaca siswa dipandang sebagai salah satu langkah awal yang diharapkan dapat mendukung terwujudnya kebermaknaan. Pengembangaan media komik tersebut memiliki fungsi ganda yaitu dilihat dari manfaatnya. Hasil penelitian ini akan bermanfaat bagi (1) sekolah sebagai sarana yang secara langsung dapat diimplementasikan untuk mendukung kegiatan atau pelaksanaan gerakan literasi sekolah dan (2) negara sebagai sarana untuk memenuhi tuntutan peningkatan kemampuan literasi masyarakat untuk memajukan dan meningkatkan daya saing bangsa.

Dapat diperkuat melalui hasil penelitian oleh Edirman (2020:19), Handayani \& Koeswanti (2020) yang membuktikan bahwa melalui media komik siswa dapat meningkatkan hasil belajarnya. Hal ini membuktikan bahwa pengembangan media komik dapat membantu siswa dan guru dalam proses pembelajaran di sekolah. Berdasarkan permasalahan yang telah diuraikan di atas, maka peneliti tertarik melakukan penelitian pengembangan dengan jududul penelitian yaitu "Pengembangan Media Komik Interaktif Cerita Mbojo Berbasis Gerakan Literasi Sekolah Untuk meningkatkan Minat Baca siswa di SDN Sari Kalampa Kecamatan Woha Kabupaten Bima”.

Tujuan kusus dalam penelitian ini adalah untuk mengetahui peningkatan minat baca siswa melalui pengembangan komik interaktif cerita Mbojo dan dengan penelitian ini diharapkan dapat dimanfaatkan sebagai program kegiatan literasi sekolah yang akan terus berlanjut sesuai dengan program Pemerintah Kabupaten Bima. Dalam penelitian ini sebagai peneliti wajib memahami dampak rendahnya minat membaca anak di SDN Sari Kalampa Kecamata Woha Kabupaten Bima, maka dari itu peneliti wajib memberikan sebuah inovasi dalam mengembangkan komik cerita Mbojo yang nantinya dapat memberikan dampak positif bagi para siswa dalam meningkatkan minat baca.

\section{TINJAUAN PUSTAKA}

\section{Pengembangan}

Pengembangan dalam pengertian yang sangat umum adalah, pertumbuhan, perkembangan yang terjadi secara perlahan (evolusi) dan perubahan secara bertahap. Menurut Putra (2011:70) \& Ilmiawan (2018: 102) pengembangan adalah aplikasi sistematis dari pengetahuan dan pemahaman, diarahkan pada produksi bahan yang bermanfaat, perangkat, dan sistem atau metode, pengembangan dan peningkatan prioritas serta proses baru untuk memenuhi persyaratan tertentu.

Penelitian pengembangan adalah sebuah penelitian yang menghasilkan suatu produk tertentu, mengkaji sesuatu dengan mengikuti alur berjalannya periode waktu, mempelajari suatu proses terjadinya atau berlangsungnya suatu peristiwa, keadaan, dan objek tertentu (Nurjanah \& Hakim, 2018; Setyosari, 2013: 221).

\section{Media Komik}

Amirulmukminin \& Syahrir (2012) menyatakan bahwa media komik adalah bentuk cerita bergambar yang dikemas sedemikian rupa sehingga dapat menarik perhatian para siswa. Hal ini juga sejalan dengan pendapatnya Sudjana dan Rivai (2010: 64) yang memberikan definisi mengenai komik yaitu "komik adalah suatu bentuk kartun yang mengungkapkan suatu karakter dan memerankan suatu cerita dalam urutan yang erat dihubungkan dengan gambar untuk memberikan hiburan kepada para pembacanya". Dari pendapat di atas maka dapat disimpulkan bahwa komik merupakan sebuah media yang disusun dalam bentuk gambar dan kata yang bertujuan untuk memberikan informasi yang ingin disampaikan kepada pembaca. Sebuah media komik selalu memanfaatkan ruang gambar dengan tata letak.

Media komik merupakan bentuk sumber belajar yang dapat membantu siswa dalam proses pembelajaran baik di dalam kelas maupun di luar kelas (Saputro, 2015). Budiarti dan Haryanto (2016: 235) menyatakan bahwa media komik berfungsi sebagai penyampaian pesan yang dikemas 
dalam bentuk yang menarik agar siswa lebih tertarik untuk kegiatan literasi sebagai bahan bacaan yang menarik, ada beberapa tahap dalam pembuatan media komik yaitu meliputi: (1) tahap pengidentifikasian target, (2) tahap pengidentifikasian warna, dan (3) pembuatan sekenario. Pengembangan media komik berbasis gerakan literasi sekolah di SDN Sari Kalampa Kecamatan Woha Kabupaten Bima bertujuan memberikan inovasi baru dalam memperkaya bahan bacaan dengan dihadirkan media komik.

Komik interaktif ini berisi gambar khas yang berurutan dilengkapi dengan panduan kata-kata yang dibuat secara berurutan dan semenarik mungkin untuk meningkatkan motivasi siswa dan minat siswa dalam membaca. Penelitian pengembangan media komik ini juga dapat membatu para siswa dalam mengembangkan kompetensi berbahasa di sekolah melalui proses kegiatan literasi oleh guru, dimana keterampilan berbahasa siswa akan tampak secara langsung dalam kegiatan komunikasinya sehari-hari.

\section{Gerakan Literasi Sekolah}

Demi mendukung kemajuan literasi masyarakat Indonesia maka Kemdikbud merancang Gerakan Literasi Sekolah yang pelaksanaannya meliputi tiga tahapan yaitu tahap pembiasaan, tahap pengembangan, dan tahap pembelajaran (Permendikbud Nomor 23 Tahun 2015). Tahap pembelajaran dilakukan dengan strategi meningkatkan kemampuan literasi disemua mata pelajaran diantaranya menggunakan buku pengayaan dan strategi membaca. Tujuan dari gerakan Literasi Sekolah yaitu untuk membiasakan dan merangsang minat murid dalam membaca dan menulis (Ilmi, Wulan \& Wahyudin, 2021).

Beers mengungkapkan dalam buku "Desain Induk Gerakan Literasi Sekolah" (Kemendikbud, 2016a:11) bahwa salah satu prinsip literasi di sekolah adalah terintegrasinya program literasi dengan kurikulum. Artinya, pembiasaan, pengembangan, dan pembelajaran literasi di sekolah bukan hanya tanggung jawab guru bahasa, melainkan semua guru mata pelajaran apapun termasuk tematik (guru kelas) karena pembelajaran muatan apapun membutuhkan bahasa, terutama proses membaca dan menulis. Fuad (2015) mengemukakan bahwa pembelajaran tematik yang memadukan beberapa konsep, metode, dan keterampilan sangat cocok dihubungkan dengan pembelajaran literasi.

\section{METODE}

\section{Metode penelitian}

Penelitian yang dilakukan dalam penelitian ini adalah penelitian pengembangan yaitu menggunakan modifikasi model desain Research and Developmen $(R \& D)$. Model ini dilakukan dengan tujuan mendapatkan prosedur pengembangan sesuai kebutuhan. Pengembangan diarahkan sebagai "process used to develop and and validate education product Borg and Gall" (dalam Sukmadinata, 2008: 169). Produk yang dimaksud adalah media komik interaktif berbasis gerakan literasi sekolah.

\section{Prosedur Penelitian}

Menurut Borg dan Gall (Sugiyono, 2015:407)., penelitian R\&D dalam pendidikan meliputi sepuluh langkah, yakni: (1) penelitian dan pengumpulan data (research and information collecting);

perencanaan (planning), yaitu menyusun rencana penelitian, merumuskan butir-butir materi secara terperinci yang mendukung tercapainya tujuan dan menyusun cerita anak bermuatan nilai-nilai karakter; pengembangan draft produk (develop preliminary from of product), yaitu mengembangkan alat pengukuran keberhasilan dan uji ahli materi; (4) uji coba lapangan awal (preliminary field testing); (5) merevisi hasil uji coba (main product revision); (6) uji coba lapangan (main field testing); (7) revisi terhadap hasil uji coba lapangan (operational product revision); (8) uji pelaksanaan lapangan (operational field testing); (9) penyempurnaan produk akhir(final product revision); (10) desiminasi dan implementasi (desimination and implemantion).

\section{Rencana Lokasi}

Penelitian tentang pengembangan media komik interaktif cerita Mbojo berbasis gerakan 
literasi sekolah dilaksanakan di SDN Sari Kalampa Kecamatan Woha Kabupaten Bima.

\section{Tehnik Pengumpulan Data}

Teknik pengumpulan data yang digunakan berupa angket uji produk, wawancara dan angket uji kebutuhan. Angket uji produk ditujukan kepada ahli media komik dan ahli isi serta bahasa dengan harapan dapat mengetahui saran dan perbaikan sehingga media komik cerita Mbojo tersusun secara sempurna. Teknik wawancara digunakan untuk mengumpulkan data yang berkaitan dengan kebutuhan pengembangan media komik menurut guru. Selanjutnya angket kebutuhan ditujukan kepada siswa dan guru dengan harapan dapat mengetahui kebutuhan pengembangan media komik interaktif cerita Mbojo.

Data kualitatif yang diperoleh dalam penelitian pengembangan ini dianalisis secara deskriptif kualitatif. Sedangkan data kuantitatif yang diperoleh dalam penelitian pengembangan ini dianalisis secara deskriptif kuantitatif. Alasan pemilihan teknik ini adalah peneliti ingin memperoleh data tingkat efektifitas, efisiensi, dan kelayakan penggunaan produk dalam penelitian pengembangan ini.

\section{Analisis Data}

Analisis data kualitatif akan diperoleh pada penelitian pengembangan secara deskriptif kualitatif, sedangkan pada analisis data kuantitatif diperoleh pada penelitian pengembangan secara kuantitatif.

\section{HASIL DAN PEMBAHASAN}

Penelitian ini dilaksanakan di SDN Sari Kalampa yang berada di Dusun Sari, Desa kalampa Kecamatan Woha Kabupaten Bima dengan subjek penelitian yaitu secara keseluruhan semua siswa yang berada di kelas rendah. Penelitian pengembangan ini menghasilkan sebuah produk berupa komik interaktif cerita mbojo berbasis gerakan literasi sekolah untuk meningkatkan minat baca siswa. Penelitian dimulai dari instrumen penelitian dan dilanjutkan dengan angket uji produk yaitu validasi oleh para ahli sebelum media komik interaktif di uji cobakan.

\section{Keterangan:}

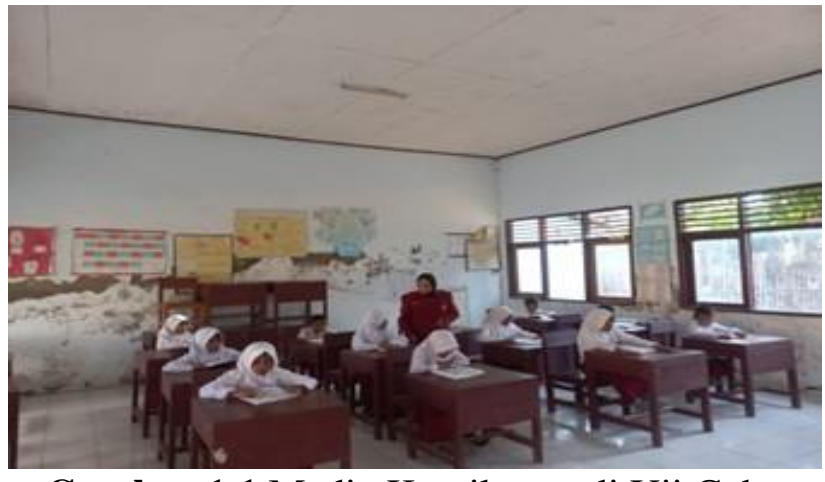

Gambar 1.1 Media Komik saat di Uji Coba

Para ahli tersebut adalah dosen validasi media, isi dan validasi bahasa. Pada lembar validasi ahli digunakan skala penilaian $1-5$ setelah itu dianalisis dengan menggunakan rumus sebagai berikut:

$$
X=\frac{\sum x}{n}
$$

$$
\begin{aligned}
X & =\text { Skor rata }- \text { rata } \\
\sum x & =\text { Jumlah skor } \\
& =\text { Jumlah penilaian }
\end{aligned}
$$

Selanjutnya nilai yang diperoleh disesuaikan dengan menggunakan kategori penilaian seperti pada tabel di bawah ini:

Tabel 1. Kategori Kelayakan Media Pembelajaran

\begin{tabular}{|c|c|c|}
\hline Penilaian & Kategori & Skor \\
\hline$X>4,2$ & Sangat baik & 5 \\
\hline $3,4<X \leq 4,2$ & Baik & 4 \\
\hline $2,6<X \leq 3,4$ & Cukup Baik & 3 \\
\hline $1,8<X \leq 2,6$ & Kurang Baik & 2 \\
\hline$X \leq 1,8$ & Sangat Kurang & 1 \\
\hline
\end{tabular}

Berikut penjelasan mengenai hasil penilaian para ahli validasi :

a. Validasi Media

Validasi media terhadap media komik interaktif cerita mbojo berbasis literasi dilakukan oleh dosen yang memiliki kompeten pada bidang media pembelajaran. Penilaian dilakukan oleh ahli validator dengan mengisi penilaian lembar validasi media yaitu dengan jumlah skornya diperoleh sebanyak 98 dari 25 indikator jumlah penilaian. Lalu setelah mengetahui itu maka skor rata-ratanya adalah 3,92 sehingga jika dikonversikan kedalam data kuantitatif maka termaksud kategori Baik. Dari penjelasan 
tersebut maka dapat disimpulkan bahwa kualitas media komik interaktif cerita mbojo berbasis literasi adalah Baik.

b. Validasi isi

Validasi isi terhadap media komik interaktif cerita mbojo berbasis literasi dilakukan oleh dosen yang memiliki kompeten pada bidang isi. Penilaian dilakukan oleh ahli validator dengan mengisi penilaian lembar validasi isi yaitu jumlah skornya diperoleh sebanyak 67 dari 15 indikator jumlah penilaian. Lalu setelah mengetahui itu maka skor rataratanya adalah 4,47 sehingga jika dikonversikan kedalam data kuantitatif maka termaksud kategori Sangat Baik. Dari penjelasan tersebut maka dapat disimpulkan bahwa kualitas isi yang digunakan dalam komik interaktif cerita mbojo berbasis literasi adalah Sangat Baik.

c. Validasi bahasa

Validasi bahasa terhadap media komik interaktif cerita mbojo berbasis literasi dilakukan oleh dosen yang memiliki kompeten pada bidang bahasa. Penilaian dilakukan oleh ahli validator dengan mengisi penilaian lembar validasi bahasa yaitu jumlah skornya diperoleh sebanyak 64 dari 15 indikator jumlah penilaian. Lalu setelah mengetahui itu maka skor rata-ratanya adalah 4,27 sehingga jika dikonversikan kedalam data kuantitatif maka termaksud kategori Sangat Baik. Dari penjelasan tersebut maka dapat disimpulkan bahwa kualitas bahasa yang digunakan dalam komik interaktif cerita mbojo berbasis literasi adalah Sangat Baik.

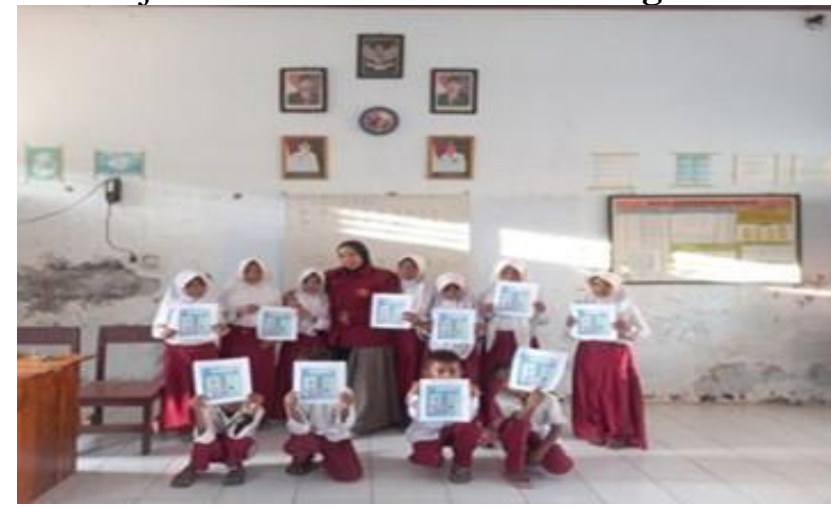

Gambar 1.2 Pasca Uji Coba Media Komik

Dari penjelasan di atas maka dapat disimpulkan bahwa media komik interaktif cerita mbojo berbasis gerakan literasi layak untuk diuji cobakan. Uji coba pada media komik ini dilakukan dengan uji coba kebutuhan yang disertai dengan respon dari siswa dan respon guru setelah menggunakan media komik. Rumus penilaian dan kategori penilaian sama halnya dengan yang digunakan sebelumnya. Berikut penjelasan uji coba kebutuhan yang dilakukan dengan memberikan angket respon siswa dan guru:

\section{a. Lembar Angket Siswa}

Subjek penelitian dalam penelitian ini yaitu secara keseluruhan semua siswa yang berada di kelas rendah. Namun untuk menganalisis hasil respon siswa maka peneliti hanya mengambil 5 orang siswa SDN Sari Kalampa yang berada di kelas rendah. Alasan peneliti mengambil 5 orang siswa yaitu sesuai dengan rekomendasi guru yangmana hasil belajar siswa dalam kategori sedang, mampu berkomunikasi dengan baik dan juga karena keterbatasan waktu yang diberikan oleh guru sehingga peneliti hanya memilih 5 orang siswa. Berikut ini hasil respon ke-5 orang siswa:

Tabel 2. Hasil Respon Siswa

\begin{tabular}{|c|c|c|}
\hline No & Nama Siswa & Skor \\
\hline 1. & AK & 49 \\
\hline 2. & NAP & 48 \\
\hline 3. & AY & 46 \\
\hline 4. & WK & 47 \\
\hline 5. & PDR & 49 \\
\hline \multicolumn{2}{|c|}{ Jumlah Skor } & 239 \\
\hline & Skor Rata-rata & 4,78 \\
\hline \multicolumn{2}{r|}{ Kategori } & Sangat Baik \\
\hline
\end{tabular}

Dari hasil tabel tersebut menunjukan bahwa media komik dapat meningkatkan minat membaca siswa hal ini dibuktikan dengan perolehan rata-rata sebesar 4,47 dengan kategori sangat baik. Selain dari itu juga peneliti melakukan wawancara terhadap siswa untuk mendukung hasil perolehan angket. Siswa menjelaskan bahwa media komik yang digunakan sangat bagus, isi ceritanya sangat menarik dan melalui media komik ini juga dapat menambah ilmu pengetahuan. Hal ini didukung dengan hasil penelitian Fahyuni dan Fauji (2017) bahwa penggunaan media komik dapat meningkatkan minat membaca dan mampu memberikan apresiasi positif dari siswa. Sama 
dengan hasil penelitian tersebut, penelitian yang dilakukan Lubis (2018) juga menghasilkan bahan ajar komik yang sangat efektif dalam meningkatkan minat baca siswa.

b. Lembar Angket Guru

Penilaian dilakukan oleh guru dengan mengisi penilaian lembar angket yaitu jumlah skornya diperoleh sebanyak 85 dari 18 indikator jumlah penilaian. Lalu setelah mengetahui itu maka skor rata-ratanya adalah 4,72 sehingga jika dikonversikan kedalam data kuantitatif maka termaksud kategori Sangat Baik. Didukung dengan hasil wawancara terhadap guru bahwa media komik ini sangat kreatif sehingga mampu memberikan manfata yang baik terhadap minap baca siswa.

\section{KESIMPULAN}

Berdasarkan hasil penelitian dan pembahasan mengenai pengembangan media komik interktif cerita mbojo berbasis gerakan literasi sekolah untuk meningkatkan minat baca siswa maka didapatkan beberapa kesimpulan yaitu media komik dapat meningkatkan minat membaca siswa hal ini dibuktikan dengan perolehan skor rata-rata dari respon siswa yaitu 4,47 yang termasuk katogori "sangat baik" dan respon guru yaitu 4,72 yang termaksud kategori "sangat baik" sehingga dari kedua respon itu maka dapat disimpulkan bahwa media komik interaktif cerita mbojo berbasis gerakan literasi sekolah layak digunakan untuk meningkatkan minat baca siswa.

\section{SARAN}

Berdasarkan penelitian pengembangan media komik interaktif cerita mbojo berbasis gerakan literasi sekolah untuk meningkatkan minat baca siswa maka dapat diberikan saran yaitu guru perlu menciptakan media pembelajaran yang kreatif agar dapat meningkatkan minta baca siswa.

\section{UCAPAN TERIMA KASIH}

Peneliti mengucapkan terimakasih kepada pihak-pihak yang telah membantu terlaksananya dan tercapainya penelitian ini terutama untuk Kepala Sekolah dan Guru-guru SDN Sari Kalampa.

\section{DAFTAR PUSTAKA}

Amirulmukminin, \& Syahrir. (2012). Media Komik terhadap Hasil Belajar. Jurnal Ilmiah Pendidikan Fisika " Lensa," 2(1), 161-165.

Fahyuni, E. F., \& Fauji, I. (2017). Pengembangan Komik Akidah Akhlak Untuk Meningkatkan Minat Baca dan Prestasi Belajar Siswa Sekolah Dasar. Halaqa: Islamic Education Journal, 1(1), 17-26.

Faizah, Dwi Utami. 2016. Panduan Gerakan Literasi Sekolah Di Sekolah Dasar. Jakarta : Dirjen Pendidikan Dasar dan Menengah Kemendikbud.

Handayani, P., \& Koeswanti, H. D. (2020). Pengembangan Media Komik untuk Meningkatkan Minat Membaca Siswa Sekolah Dasar. Jurnal Basicedu, 4(2), 396-401.

Ilmi, N., Wulan, N. S., \& Wahyudin, D. (2021). Gerakan Literasi Sekolah dalam Meningkatkan Minat Baca Siswa Sekolah Dasar. Edukatif: Jurnal Ilmu Pendidikan, 3(5), 2866-2873.

Ilmiawan, A. (2018). Pengembangan Buku Ajar Sejarah Berbasis Situs Sejarah Bima (Studi Kasus pada Siswa Kelas X MAN 2 Kota Bima). JISIP (Jurnal Ilmu Sosial Dan Pendidikan), 2(3), 102-106.

Kemendikbud. 2016a. Desain Induk Gerakan Literasi Sekolah. Jakarta: Dirjen Dikdasmen Kemendikbud.

Lubis, M. A. (2018). Pengembangan Bahan Ajar Komik untuk Meningkatkan Minat Baca PPKn Siswa MIN Ramba Padang Kabupaten Tapanuli Selatan. Jurnal Tarbiyah, 25(2), 152-173.

Nurjanah, E., \& Hakim, D. (2018). Pengembangan Bahan Ajar Materi Mencerna (Menyimak Cerita Anak) Berbasis Cerita Anak Majalah Bobo pada Siswa Kelas VI MI Darun Najah 1 Jatirejo Mojokerto. Jurnal Bidang Pendidikan Dasar (JBPD), 2(1), 69-83. Setyosari, Punaji. 2013. Metode Penelitian Pendidikan dan Pengembangan. Jakarta: Kencana. 
Saputro, A. D. (2015). Aplikasi Komik sebagai Media Pembelajaran. Muaddib, 05(01), $1-19$.

Sugiyono. 2015. Metode Penelitian Pendidikan Kuantitatif, Kualitatif, dan $R \& D$. Bandung: Alvabeta.

Sudjana dan Rivai. 2010. Media Pembelajaran. Bandung: Sinar Baru Algensindo.

Susanto, Ready. 2008. Buku Paket XI SMA/SMK/MAK Bahasa Indonesia Kurikulum 2013. Bandung: Nuansa.

Sukmadinata,N.,S. 2006. Metode Penelitian Pendidikan. Bandung: Remaja Rosdakarya.

Putra, Nusa. 2011. Research and Development (Penelitian dan Pengembangan: Suatu Pengantar). Jakarta: PT. Raja Grafinda Persada.

UNESCO. 2020. http://webcapp.ccsu.edu/?news $=1767 \&$ data.

USAID. 2014. Pembelajaran Literasi Kelas Awal SD/MIdi LPTK. http://repository.stkipgetsempena.ac.id/ bitstream/549/1/Pembelajaran_Literasi _dikelas_Awal_di_LPTK.pd 